Stanisław Łucarz SJ

\title{
ŚWIĘTOŚĆ I ŚWIADECTWO W PIERWOTNYM CHRZEŚCIJAŃSTWIE ${ }^{1}$
}

Świętość i świadectwo są w chrześcijaństwie ściśle ze sobą powiązanie. Nie jest tak jednak od samego początku. Owo rozbicie w człowieku, które jest skutkiem grzechu, również w tej dziedzinie mocno się zaznacza. Dopiero w Jezusie Chrystusie i Jego świętych ujawnia się jedność i harmonia rozbitych przez grzech sfer w człowieku.

W tekście tym spojrzymy najpierw na świętość i jej historię tak, jak jawi się nam ona w Starym i Nowym Testamencie, a potem w historii Kościoła. Potem uczynimy podobnie ze świadectwem, by następnie zobaczyć ich zasadniczą jedność i nierozerwalność. Jest bowiem tak, że nie może być świętości bez świadectwa, a świadectwo bez świętości okazuje się egzystencjalnym fałszem, a więc przestaje tak naprawdę być samym sobą.

\section{Świętość w Starym Testamencie}

Jest rzeczą uderzającą i już samą w sobie wymowną, że zarówno hebrajski ter-

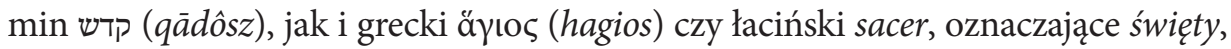
mają pochodzenie pogańskie. Co więcej, samo słowo (qādôsz) nie pochodzi pierwotnie z języka hebrajskiego, lecz z języka kananejskiego, i zostało przez Izraelitów przejęte. Pamiętać trzeba, że religia kananejska była dla Izraelitów religią ohydną, i to z wielu względów. Zwłaszcza przez jej kulty płodności, w których dopuszczano się praktyk orgiastycznych i prostytucji sakralnej. Tak więc - można by powiedzieć - od początku słowa te skażone są pogaństwem, i to w znacznie większej mierze niż inne słowa, gdyż pochodzą z samego centrum religijności pogańskiej.

1 Wykład opracowany na podstawie: O. Proksch, „Ayıo (Hagios)”, [w:] G. Kittel, Theologisches Wörterbuch zum Neuen Testament, Stuttgart 1933, I, 88; X. Léon-Dufour, Słownik teologii biblijnej, tłumacz. Kazimierz Bp Romaniuk, Poznań-Warszawa 1973, s. 949-952, 972-977. 
Początkowo w kontekście pogańskim słowa te oznaczały coś oddzielonego, odciętego, wyłączonego z normalnego użytku, co więcej, nawet coś przeklętego; dotyczy to zwłaszcza łacińskiego sacer. Związane jest to z ścisłym oddzieleniem w religiach pogańskich sacrum i profanum. Świętość i to, co się z nią wiązało, było i jest do tej pory w religijności pogańskiej otoczone lękiem - tabu. Rzeczy święte to te, których się nie dotyka lub do których nie wolno się zbliżać inaczej, jak tylko przy zachowaniu warunków czystości rytualnej. Rzeczy święte wywołują mieszane uczucia: $z$ jednej strony fascynacji, a $z$ drugiej przerażenia.

Tak jest też na początku w Biblii. Mojżesz słyszy od Boga: „Zdejm sandały, bo miejsce, na którym stoisz, jest ziemią świętą"2. Święta jest Arka Przymierza i święte jest Święte Świętych, a więc miejsce w świątyni, w którym była ona przechowywana. Do Świętego Świętych i Arki też mogli zbliżać się tylko kapłani i lewici, i to po specjalnym oczyszczeniu. Stary Testament w wielu miejscach bardzo tę kultyczną świętość podkreśla.

Objawienie Boga pokazuje jednak coraz głębsze wymiary świętości. Nade wszystko święty jest Bóg sam i Jego imię. To przez Niego wszystko się uświęca. Z tym że początkowo Izraelici postrzegają tę świętość Boga podobnie jak inne narody. Objawiona po raz pierwszy podczas teofanii na Synaju, świętość Jahwe jest potęgą przerażającą i tajemniczą zarazem, gotową zniszczyć wszystko, co się do niej zbliża, lecz będącą również w stanie zsyłać błogosławieństwa na tych, którzy przyjmują Arkę, miejsce jej zamieszkania.

Stopniowo świętość ta zmienia swoje oblicze, a raczej ujawnia coraz wyraźniej swą wewnętrzną naturę. Bóg Izraela zdziera kolejne zasłony, które oddzielają Go od swojego ludu. Stopniowo zaczyna dzielić się z nim swoją świętością, czyli uświęca go. Już nie tylko rzeczy i miejsca przeznaczone do kultu są święte, ale święci stają się ludzie, których Bóg wybiera. Co więcej, święty staje się sam naród wybrany. Izrael jest szczególną własnością Boga, „ludem świętym”3.

Siła tego narodu tkwi nie w zbrojnych zastępach ani sprytnej dyplomacji, lecz $\mathrm{w}$ wierze $\mathrm{w}$ Jahwe, świętego Izraela ${ }^{4}$. On daje swojemu ludowi nie tylko to, co go odróżnia od innych narodów, lecz także pełne poczucie bezpieczeństwa i niezwyciężonej ufności. Co więcej, wzywa ten lud, aby stawał się świętym: „Bądźcie świętymi, bo i Ja jestem święty, Jahwe, Bóg wasz"5. To wezwanie ukazuje nowy wymiar świętości. Świętość jest nie tylko darem, ale i owocem ludzkiego starania. Nie tylko Bóg uświęca, ale i człowiek ma tu do odegrania swoją ważną rolę. Już tu widać, że świętość zakłada wolność człowieka i jest dla niej wyzwaniem.

\footnotetext{
Wj 3, 5 .

Wj 19,6.

Por. Iz 7, 9.

5 Kpł 19, 2; 20, 26.
} 
Aby się świętość ludu dopełniła, nie tylko Bóg wybiera swój lud, ale i lud ma wybrać Boga, a to oznacza oczyszczenie, nie tyle oczyszczenie o charakterze kultycznym, bo takie oczyszczenie jest tylko zewnętrzne, ale oczyszczenie serca. Polega ono przede wszystkim na oczyszczeniu $z$ wszelkich form bałwochwalstwa. To warunek sine qua non świętości. Ludzkie serce musi być czyste, oczyszczone z wszelkiego pogaństwa i jego bożków. Doświadczenie Izraela wskazuje jednak, że lud nie jest w stanie sam oczyścić się w ten sposób. Bóg czyni mu z tego powodu wyrzuty, iż Izraelici zbeszcześcili Jego imię, nie okazali pośród ludów Jego świętości, dlatego też zapowiada przez proroka Ezechiela, że On sam dokona tego oczyszczenia ${ }^{6}$. Widać zatem w tym proroctwie, że misją Izraela jest nie tylko to, by lud był święty, ale też i to, by tę świętość okazywał wobec świata. Już więc ostatnie akordy Starego Testamentu wskazują, iż świętość ma być połączona ze świadectwem o niej.

Stary Testament doprowadza nas do objawienia, że świętość jest istotą i naturą Boga. Ta istota i natura Boga, choć w Starym Testamencie objawia się coraz bardziej, pozostaje zasadniczo zakryta. Odsłania się ona w pełni dopiero w Nowym Testamencie zgodnie z zasadą, którą sformułował św. Augustyn: „Novum in Vetere latet, Vetus in Novo patet".

\section{Świętość w Nowym Testamencie}

Świętość Boga ujawnia się w pełni w Jezusie Chrystusie. Nawet duchy nieczyste, które Jezus wyrzuca, mówią o Nim, że jest „Świętym Bożym”7. Owa świętość Jezusa nie polega na tym, że jest niedostępny dla zwykłych śmiertelników, że trzeba jakieś specjalnej czystości rytualnej, by wejść z Nim w kontakt. Jest wprost przeciwnie. Staje się to powodem krytyk i wyrzutów, jakie czynią mu faryzeusze i uczeni w Piśmie: „Ten przyjmuje grzeszników i jada z nimi” ${ }^{8}$. To zupełnie inne oblicze świętości niż to, które było w religiach pogańskich i na początku Starego Testamentu. W Jezusie świętość staje się tak bliska i niebudząca lęku, że nawet najbliżsi Jezusowi nie mogą w nią uwierzyć. Stąd też podczas ostatniej wieczerzy apostoł Filip zwraca się do Jezusa z prośbą: „Panie, pokaż nam Ojca, a to nam wystarczy”, i otrzymuje zaskakującą odpowiedź: „Filipie, tak długo jestem

6 Por. Ez 36, 16-29: „Zabiorę was spośród ludów, zbiorę was ze wszystkich krajów i przyprowadzę was z powrotem do waszego kraju, pokropię was czystą wodą, abyście się stali czystymi, i oczyszczę was od wszelkiej zmazy i od wszystkich waszych bożków. I dam wam serce nowe i ducha nowego tchnę do waszego wnętrza, odbiorę wam serce kamienne, a dam wam serce $\mathrm{z}$ ciała”.

7 Łk 4, 34.

$8 \quad$ Łk 15, 2. 
z wami i jeszcze mnie nie poznałeś: kto widzi mnie, widzi Ojca..." , „Ja i Ojciec jedno jesteśmy..."10. Całe życie Jezusa, a zwłaszcza Jego Misterium Paschalne, jest objawieniem się świętości, a zatem istoty i natury Boga. W Jezusie w pełni objawia się istota i natura Boga. Tą istotą zaś i naturą jest miłość Boga Trójjedynego. „Świętość polega na miłości” - powie św. Jan Paweł II na Błoniach krakowskich ${ }^{11}$, bo Bóg jest miłością.

\section{Świadectwo}

W starożytności „świadectwo” (gr. martyría) oznacza przede wszystkim poświadczenie jakiegoś wydarzenia - zwłaszcza przymierza czy innego ważnego faktu. Tak jest w tekstach homeryckich, jak i w Starym Testamencie. Stąd Arka Przymierza nazwana jest też Arką Świadectwa. Tak więc świadectwo odnosi się przede wszystkim do spraw zewnętrznych, nierzadko o charakterze sądowym. Stary Testament nie zna pojęcia świadectwa opartego na przekonaniu czy na doświadczeniu wewnętrznym. Zawsze świadectwo odnosi się do faktów obiektywnych. Jak we wszystkich innych dziedzinach objawienia, tak i w przypadku tego słowa przełom i pełnia przychodzą wraz z Jezusem Chrystusem. W Jezusie świadectwo staje się wyrażeniem tego, co jest we wnętrzu. Jezus daje świadectwo o swojej relacji z Ojcem. Wchodzimy zatem w życie wewnętrzne, co więcej, w życie wewnętrzne Trójcy. Życie Jezusa jest świadectwem o wewnętrznej naturze Boga, która jest świętością i miłością zarazem, i która torowała sobie powoli drogę do człowieka poprzez Stary Testament, pokonując stopniowo ludzkie wyobrażenia o świętości, skażone przez grzech. Jezus jest żywym świadectwem natury Boga. Sam mówi o sobie w modlitwie skierowanej do Ojca: „Objawiłem im Twoje imię i nadal będę objawiał, aby miłość, którą Ty Mnie umiłowałeś, w nich była i Ja w nich"12. Jeśli w Biblii „imię” oznacza istotę i naturę osoby, to Jezus objawia właśnie naturę Ojca, którą jest miłość, czyli świętość. Objawia ją nie tyle słowami, ile przede wszystkim swoim życiem i śmiercią. Jezus po to przyszedł na świat, jak wyznaje przed Piłatem, aby dać świadectwo prawdzie ${ }^{13}$. Jakiej prawdzie Jezus daje świadectwo? Prawdzie o świętości Boga, czyli o Jego miłości, która nie jest żadną abstrakcją ani nauką. Jest żywą osobą. Jak to bowiem ostatnio stwierdziła

$9 \mathrm{~J} 14,8-9$.

$10 \mathrm{~J} \mathrm{10,} 30$.

11 Por. Homilia w czasie Mszy św. beatyfikacyjnej o. Rafała Kalinowskiego i brata Alberta Adama Chmielowskiego, Kraków, 22 czerwca 1983, www.karmel.pl/hagiografia/kalinowski/ kosciol/baza.php?id=12 (7.07.2016).

12 J 17, 26.

13 Por. J 18, 37. 
osoba bliska ojcu świętemu Janowi Pawłowi II, dr Wanda Półtawska: „Miłości nie ma. Są tylko osoby, które kochają" ${ }^{14}$. Stąd też to osoba jest miłością i miłość osobą. W Jezusie, w Jego osobie, świętość i świadectwo się zlewają, stają się jednym. To jest nowa jakość, która, owszem, zawsze była w Bogu, ale na ziemi pojawia się po raz pierwszy w Osobie wcielonego Syna Bożego.

Najwyższym świadectwem świętości i miłości zarazem jest Jezus umierający na krzyżu, bo tam objawia się najwyższa - boska - forma miłości, posuwająca się aż do miłości nieprzyjaciół.

\section{W tę samą dynamikę świętości i świadectwa wchodzi pierwotne chrześcijaństwo}

Jezus modli się za swoich uczniów: „Ojcze, uświęć ich w prawdzie. Słowo Twoje jest prawdą. Jak Ty Mnie posłałeś na świat, tak i Ja ich na świat posłałem. A za nich Ja poświęcam w ofierze samego siebie, aby i oni byli uświęceni w prawdzie" ${ }^{15}$. To niezwykły tekst łączący w sobie świętość i świadectwo dla uczniów Chrystusa. Jezus modli się za nich, aby byli uświęceni w prawdzie. Tą prawdą jednak jest On sam jako objawienie miłości Boga. Uczniowie - a więc chrześcijanie - mają być uświęceni w Nim, czyli mają mieć w sobie Jego naturę. I tak jak Ojciec posłał Jezusa na świat, by dał świadectwo prawdzie, czyli Boskiej naturze, którą sam w sobie nosi jako Syn Boży, tak też i chrześcijanie mają być świadkami tej samej osobowej prawdy, która jest miłością. Stąd też pierwotni chrześcijanie - ochrzczeni - nazywali się świętymi. Szczególnie wyraźne jest to w listach św. Pawła. Nie chodzi tu jednak o świętość w naszym dzisiejszym, moralistycznym, znaczeniu. Chodzi o to najgłębsze znaczenie świętości, którym jest - powtórzmy to jeszcze raz - sama natura Boga, a więc miłość ukrzyżowana i zmartwychwstała objawiona w Jezusie Chrystusie.

Tuż przed swoim wstąpieniem do nieba Jezus mówi do uczniów: „Weźmiecie moc Ducha Świętego, kiedy zstąpi na was, i będziecie mi świadkami w Jerozolimie, i aż po krańce ziemi!"16. Tak też się dzieje. Pierwsi święci Kościoła są nazywani martyres, co nie znaczy wcale „męczennicy”. W języku greckim martys albo martyr znaczy świadek, a martyría to nie męczeństwo, lecz właśnie świadectwo. W aktach męczenników ojcowie apostolscy prześcigali się w udowadnianiu, że to nie męczennicy walczyli i zwyciężali, ale walczył w nich i zwyciężał Chry-

14 www.rp.pl/Plus-Minus/302129986-Wanda-Poltawska-Ludzie-nie-potrafia-kochac. html\#ap-15 (14.02.2016).

15 J $17,17-19$.

16 Dz 1, 6-8. 
stus. Chodziło nie o to, żeby pokazać bohaterstwo tych braci i sióstr, ale moc Chrystusa w nich - czyli właśnie ich świadectwo o Chrystusie. Św. Polikarp nazywa męczenników żywymi obrazami prawdziwej miłości ${ }^{17}$. Szczególny wyraz tej prawdy znajdujemy w męczeństwie św. Felicyty. Felicyta cierpi i jęczy w więzieniu w czasie porodu, co powoduje ironiczną uwagę jednego ze strażników: „o, jak będzie jęczała rzucona dzikim zwierzętom”. Felicyta odpowiada: „Teraz ja sama cierpię to, co cierpię, tam zaś będzie we mnie Ktoś inny, który będzie cierpiał za mnie, ponieważ za niego mam być umęczona" ${ }^{18}$. Istotą świętości męczenników był (jest) działający w nich Chrystus. Nie były to ich dokonania, ale dzieło Chrystusa w nich. Ich dokonaniem było tylko to, czy raczej aż to, że Mu zaufali i pozwolili się prowadzić. Kościół pierwotny bardzo mocno podkreślał, iż to Chrystus zwyciężał w ich słabości. Pozostało to w słowach prefacji o męczennikach, którymi Kościół modli się do dziś: „Ty sprawiasz, że moc w słabości się doskonali i umacniasz słabych ludzi do złożenia świadectwa wierze, przez naszego Pana Jezusa Chrystusa" ${ }^{19}$. Nieco myląca jest współczesna terminologia kościelna stosowana podczas procesów beatyfikacyjnych, mówiąca o heroiczności cnót. Dla Kościoła pierwotnego męczennicy nie byli herosami. Wręcz przeciwnie. Byli słabymi ludźmi, w których z mocą działał Chrystus, i przez to właśnie byli Jego świadkami. Więcej nawet! Kościół pierwotny wystrzegał się i zakazywał ludzkiego li tylko bohaterstwa. Nie wolno było zgłaszać się dobrowolnie na męczeństwo. Męczeństwo miało być wyrazem woli Boga, a nie człowieka. Doświadczenie Kościoła wskazywało, że owi dobrowolnie zgłaszający się na męczeństwo zwykle upadali. Nie chodziło przecież o sam fakt poniesienia śmierci, ale o motywację, na którą z jednej strony składało się wybranie przez Boga, widoczne w faktach $\mathrm{z}$ historii danego człowieka, a $\mathrm{z}$ drugiej - przyjęcie tego wybrania $\mathrm{z}$ wiarą i ufnością.

Już za czasów św. Augustyna zaczęło się to, co w naszych czasach stało się oczywiste: utożsamianie martyrium rozumianego pierwotnie jako świadectwo z męczeństwem. Co więcej, zaczęto martyrium rozumieć nie jako świadectwo, ale jako mękę. Tymczasem męka czy cierpienie nie mają same z siebie żadnej wartości. Wręcz przeciwnie, mają charakter wybitnie negatywny. Dlatego św. Augustyn będzie podkreślał: „Martyrem non facit poena sed causa”. Nie chodzi o mękę, ale o świadectwo. Nie chodzi o to, że ktoś cierpi, ale o to, dla kogo i z jakiego powodu cierpi.

17 Por. Św. Polikarp, Do Filipian, 1,1, [w:] Pierwsi świadkowie. Pisma Ojców Apostolskich, tłum. A. Świderkówna, oprac. M. Starowieyski, Kraków 1978, s. 156.

18 Męczeństwo św. Felicyty i Perpetuy, 15, [w:] Męczennicy (Ojcowie żywi, 9), red. E. Wipszycka, M. Starowieyski, Kraków 1991, s. 261n; M. Starowieyski, Męczennicy - uczniami Chrystusa, [w:] „Warszawskie Studia Teologiczne” XXI (2008), s. 43-52.

${ }_{19}$ Mszał rzymski dla diecezji polskich, Poznań 2009, s. 89. 
Kiedy mija czas świadectwa polegającego na oddawaniu życia za Chrystusa w sposób krwawy, pojawia się inny rodzaj świadków. Nazywa się tych ludzi „martyres tou pneumatos" - to świadkowie ducha - co tłumaczy się też jako męczennicy ducha. Nastaje czas najpierw ojców i matek pustyni, a potem innych form świętości i jej świadectwa. Wszystkie charyzmaty Kościoła od jego początku aż po dzień dzisiejszy są konkretną, historyczną formą świętości i świadectwem zarazem. Świętość i świadectwo to w chrześcijaństwie dwie strony tego samego medalu, bo nie może być miłości bez wyrażania jej na zewnątrz.. Jeśli nie widać, że jest się uczniem Jezusa, to się nim po prostu nie jest...

Jeśli dobrze się przyjrzeć, tak świadectwo przeżywał i św. Jan Paweł II. Jego świadectwo nie było aktorstwem czy efektem jego wysiłku. Każdy, a zwłaszcza ci, którzy go znali bliżej, widzieli, że to świadectwo było czymś naturalnym, było wyrazem świętości, którą nosił wewnątrz, a która wynikała z jego głębokiej relacji z Bogiem. To się czuło. W czasie moich studiów w Rzymie w latach osiemdziesiątych podczas spotkania jezuitów z kardynałem Carlo Maria Martinim, któryś ze współbraci - nie Polak - zapytał go o papieża. Pierwsze słowa jego odpowiedzi brzmiały: „Abbiamo un papa mistico” - „Mamy papieża mistyka”. To z mistyki płynęła owa nadzwyczajna moc, która objawiała się w nim szczególnie w tym okresie jego życia, kiedy słabły jego ludzkie siły. Jest rzeczą zadziwiającą, że przeprowadzane właśnie $\mathrm{w}$ tamtych latach badania demoskopowe w Niemczech wskazywały, iż bardzo wielu protestantów (ponad 50\%), którzy nie uznają papieża, uważało go za świadka Chrystusa. Tak więc także w Janie Pawle II świętość i świadectwo stanowily dwie strony tej samej monety, albo raczej tej samej osoby.

\section{Abstract}

\section{Holiness and Witness in Early Christianity}

Holiness is a phenomenon present in all religions, although it does not necessarily manifest itself in the same way. In ancient pagan religions it meant a reality very deeply split. It was at the same time tremendum et fascinosum (awe-inspiring and fascinating). Also the Jews in the Old Testament experienced the holiness of God in a similar manner. But God's revelation gradually revealed a different face of His holiness. Step by step God became closer to his people. He shared His holiness with his people and hence also the people of God became holy. It become clear already in the Old Testament that holiness is the inner nature of God. Jesus Christ revealed that this inner nature of God is Love, the crucified and resurrected Love, which loves even the enemies. The holiness 
in Jesus is no more awe-inspiring. It is His open arms on the cross drawing all people to Himself.

The revelation of God's inner nature is nothing other than the witness to the truth about Love. Holiness and witness are two sides of the same coin in the life of Jesus. They are absolutely inseparable. The early Christians understood and lived holiness in the same way. For Christians holiness was the manifestation of the nature of God in their life, at the beginning in martyrdom, which in Greek originally meant, witness. The martyrs were and are witnesses of God's love and power. Their holiness is not their own achievement, but the wonder of God in their weakness. Also St. Pope John Paul II understood and lived his holiness this way. 